\title{
Chemical and Spectroscopic Characteristics of Anthrosol (Amazonian Dark Earth) and Surrounding Soil from the Brazilian Amazon Forest: Evaluation of Mineral and Organic Matter Content by Depth
}

\author{
Lucas R. Bento, ${ }^{a}$ Isabela C. Constantino, ${ }^{a}$ Amanda M. Tadini, ${ }^{b}$ Camila A. Melo, ${ }^{a}$ \\ Odair P. Ferreira, ${ }^{c}$ Altair B. Moreira ${ }^{a}$ and Márcia C. Bisinoti ${ }^{\oplus * a}$ \\ ${ }^{a}$ Laboratório de Estudos em Ciências Ambientais (LECA), Instituto de Biociências, \\ Letras e Ciências Exatas, Universidade Estadual Paulista Julio de Mesquita Filho (Unesp), \\ 15054-000 São José do Rio Preto-São Paulo, Brazil \\ ${ }^{b}$ Embrapa Instrumentação, 13560-970 São Carlos-SP, Brazil

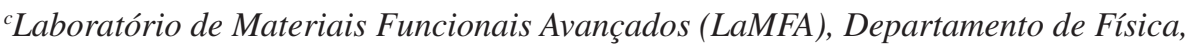 \\ Universidade Federal do Ceará, 60440-554 Fortaleza-CE, Brazil
}

\begin{abstract}
The chemical and spectroscopic characteristics of soil organic matter (SOM) isolated from Amazonian dark earth (ADE) and surrounding soil (SR) were evaluated according to the soil depth. The results showed opposite trends for the soils. While ADE featured SOM with a greater aromatic condensation degree and greater hydrophobicity in the top layer, the SR showed more aliphatic and polar SOM. The SOM arrangement from ADE was less hydrophobic, aromatic, and more polar in depth. In contrast, the SOM from SR showed an increase in molecular weight and hydrophobicity. Besides the aromatic protection in the SOM from ADE, there was organo-mineral protection through binding to soil minerals. This suggested that the SOM from ADE was protected by its hydrophobicity and interaction with minerals compared with that from the SR, thereby showing that the combination of both characteristics is important to create new technologies for soil carbon storage.
\end{abstract}

Keywords: "Terra Preta de Índio", organo-mineral interaction, soil organic matter, iron, aluminum

\section{Introduction}

The Amazon is the largest Brazilian biome, and it is rich in biodiversity and acts as a significant carbon reservoir. ${ }^{1,2}$ The Brazilian Amazon forest can be divided into eco-regions that present individual biotic and abiotic characteristics. The Amazon forest contains land strips called "Terra Preta de Índio" or Amazonian dark earth (ADE). These ADE sites can be found in different ecoregions with a large distribution across the Amazon. ${ }^{3}$ ADE soils are considered anthropogenic because they contain evidence of human activity as well as plant and animal residues, black carbon (formed by the incomplete combustion of biomass), ashes, and ceramics. ${ }^{4-7}$ The burning of these anthropogenic residues was a waste management strategy. It was likely a frequent practice,

*e-mail: marcia.bisinoti@unesp.br and resulted in a horizon rich in organic matter $(\mathrm{OM})$; this differentiates ADE soils from surrounding soils (SR), which are usually infertile. ${ }^{4,6,8-10}$ The layer that is rich in OM has a variable depth with an average of 40-50 $\mathrm{cm}$ for ADE, while the OM in the SR only constitutes the top layer $(10-20 \mathrm{~cm})$. Besides the OM content, ADE soils are rich in nutrients such as calcium, magnesium, and phosphorus; ADE soils also show microbiological diversity. ${ }^{10}$

ADE soils are highly fertile because the $\mathrm{OM}$ is present in recalcitrant and reactive forms, which is attributed to the presence of carbon nanoparticles $(2-8 \mathrm{~nm})$ with a graphitelike core and oxidized surface. ${ }^{11-13}$ Thus, graphite-like structures prolong the amount of time that the carbon is in the soil and the oxidized surface promotes the increased cation exchange capacity of the soil, thereby increasing the retention of nutrients. This practice inspired the production of pyrochar/hydrochar for soil applications (biochar) worldwide in efforts to mimic some of the properties of ADE soils. ${ }^{14,15}$ 
OM is naturally present in soil, which the characteristics it displays depend on environmental conditions. Studies have indicated that humic substances (HS), which are part of the soil organic matter (SOM), are composed of small molecules that are stabilized by weak interactions such as hydrogen bonds, hydrophobic interactions (van der Waals, $\pi-\pi$, and $\mathrm{CH}-\pi$ ), and ion bridges. ${ }^{16-19}$ Humic substances influence soil structure, water holding capacity, $\mathrm{pH}$, and adsorption of cations and organic compounds. Dissolved organic matter (DOM) represents a small part of SOM. It is the most mobile and active fraction of SOM, and plays an important role in soil chemical and biological processes. ${ }^{20}$

In the past, it was believed that $\mathrm{OM}$ was stabilized in the soil by humification, in which OM undergoes condensation reactions that form aromatic structures. ${ }^{21}$ We now know that SOM recalcitrance cannot only be attributed to the chemical energy stored in covalent bonds. The accumulation of OM within soil is attributed to the interactions with the mineral soil particles and its self-hydrophobic associations. ${ }^{22,23}$ The SOM accumulation due to the adsorption/incorporation into minerals generates aggregates of different sizes, which results in the restriction of access of microorganisms and their water soluble exoenzymes. ${ }^{24-27}$ Metal oxides, mainly iron and aluminum, play an important role in SOM stabilization due to SOM sorption, which is an efficient way to protect SOM from microbial/enzymatic degradation. ${ }^{22,23,28-30}$ Brazilian soils are classified mainly as Ultisols and Oxisols. They occupy approximately $58 \%$ of the territory and are highly weathered, acidic, and rich in iron and aluminum, which can help the stability of SOM. ${ }^{31}$

Existing ADE studies have focused on the presence of black carbon or the aromatic nature and stock nutrients of SOM. ${ }^{4,32}$ Few works have tried to understand the nature of changes in OM according to soil depth and the relationship between SOM and soil minerals. ${ }^{32,33}$ SOM undergoes changes at depth caused by biotic and abiotic processes. The top layer usually has an input of fresh OM and higher microbiological activity, ${ }^{34}$ while at depth the $\mathrm{OM}$ is more humified and has different ages. ${ }^{35}$ Moreover, the plant cover influences the types of OM. ${ }^{36}$ However, the OM dynamics do not follow the same pattern for all soils, which is dependent on soil properties. Besides the natural influences on the SOM of ADE, anthropogenic influences may change the OM dynamics, which can be related with the human occupation and/or different soil usage. ${ }^{32}$ Further, to the best of our knowledge, the ADE site studied in this work has not yet been investigated. Thus, the aim of this study was to assess the chemical and spectroscopic characteristics of SOM through the HS and DOM isolated from ADE and SR at different depths in order to evaluate the SOM dynamics and determine if there are different interactions between the minerals and SOM in the studied soils.

\section{Experimental}

\section{Description of the study area and soil sampling}

Soils were sampled in the municipality of Maués, Amazonas state, around the Pau-Rosa National Forest with authorization by the Chico Mendes Institute for Biodiversity Conservation, Ministry of the Environment (SISBio No. 50042-2) and the National System for the Management of Genetic Heritage and Associated Knowledge (SISGen No. A0018C2). The ADE soil

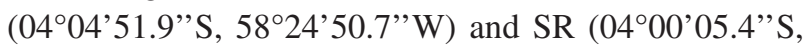
$58^{\circ} 24^{\prime} 49.0^{\prime \prime} \mathrm{W}$ ) samples were collected sequentially using a manual post hole digger at depths of $0-20 \mathrm{~cm}$, $20-40 \mathrm{~cm}, 40-60 \mathrm{~cm}, 60-80 \mathrm{~cm}$, and 80-100 cm. The ADE soil (Anthrosol) was collected from an area of native and dense vegetation and the SR was collected from an area with soil characteristics of the region (Yellow Oxisol) near the ADE site. Figure S1 in the Supplementary Information (SI) section shows the collection sites within the Amazon state. The layers were classified by means of the Munsell color chart, and the results are reported in the SI section (Table S1). The samples were dried at room temperature, homogenized, and sieved at $2 \mathrm{~mm}$ to remove roots, ceramics, and vegetation.

\section{Soil analyses}

Soil granulometry was determined after removing carbonate and $\mathrm{OM}$ using $\mathrm{H}_{2} \mathrm{O}_{2}$ (Synth, Diadema-SP, Brazil; $30 \% \mathrm{v} / \mathrm{v})$. Coarse and fine sands were fractionated by a sieve and clay and silt were determined using the pipette method. ${ }^{37}$ The $\mathrm{pH}$ value of the soils was measured using deionized water $(1: 2.5 \mathrm{~m} / \mathrm{v})$. The carbon, nitrogen, and hydrogen contents were determined using an elemental analyzer (Fisons, EA 1108, USA). The total iron, aluminum, phosphorus, calcium, zinc, copper, and potassium concentrations were quantified by flame atomic absorption spectroscopy (FAAS; Varian, AA240FS, USA) on the samples previously digested with concentrated $\mathrm{HNO}_{3}$ (Synth, Diadema-SP, Brazil; 65\%) and $\mathrm{H}_{2} \mathrm{O}_{2}$ (Synth, Diadema-SP, Brazil; 30\% v/v) under heating according to EPA method 3050b. ${ }^{38}$ The OM and ash contents were determined according to ASTM D2974-14. ${ }^{39}$ Iron and aluminum in amorphous oxides $\left(\mathrm{Fe}_{0}\right.$ and $\mathrm{Al}_{0}$, respectively) were extracted from the soil layers using ammonium oxalate $(\mathrm{pH} 3){ }^{40}$ Iron and aluminum in total pedogenic oxides $\left(\mathrm{Fe}_{\mathrm{d}}\right.$ and $\mathrm{Al}_{\mathrm{d}}$, respectively) were extracted using the sodium 
dithionite-citrate-bicarbonate method. ${ }^{41}$ Iron and aluminum forms that were bonded to SOM were extracted using the pyrophosphate method. ${ }^{42}$ Five extractions were performed in each layer sample to ensure the complete extraction of iron/aluminum forms. The extracts were then combined for further analysis. The procedures were performed in triplicate and the iron and aluminum forms were successively quantified by FAAS (Varian, AA240FS, USA).

\section{Soil organic matter isolation and analyses}

The humic substances from ADE (HS-ADE) and SR (HS-SR) were isolated in alkaline solution $\left(0.1 \mathrm{~mol} \mathrm{~L}^{-1}\right.$ of $\mathrm{NaOH})$ for $4 \mathrm{~h}$ at a proportion of 1:10 (m/v). After centrifugation (10000 rpm), the soluble fraction was dialyzed (Fisherbrand, USA; molecular weight cutoff of $6000-8000 \mathrm{D})$ against deionized water $(18 \mathrm{M} \Omega \mathrm{cm})$ until there were no changes in the conductivity. Purified HS was freeze-dried.

The carbon, hydrogen, and nitrogen contents were determined by an elemental analyzer (Fisons, EA 1108, USA); the oxygen content was obtained by the difference between the ash and CHN contents $(\mathrm{O}=100-(\mathrm{C}+\mathrm{H}+\mathrm{N}+\mathrm{ash}))$. The ashes were determined by thermal degradation (PerkinElmer, TGA-4000, USA) using $3.3 \mathrm{mg}$ of HS according to a method adapted from de Melo Benites et al..$^{43}$ The sample weight was stabilized per $1 \mathrm{~min}$ at $30{ }^{\circ} \mathrm{C}$ and heated at $10{ }^{\circ} \mathrm{C} \mathrm{min}^{-1}$ to $700{ }^{\circ} \mathrm{C}$ in an oxygen atmosphere. The contents of carbon, hydrogen, nitrogen, and oxygen were recalculated on an ash-free basis. Fourier transform infrared spectroscopy (FTIR) analyzes were carried out using an attenuate total reflectance (ATR) accessory (PerkinElmer, Spectrum Two UATR, USA). The spectra were transformed in transmittance mode: acquired with 30 scans, a resolution of $4 \mathrm{~cm}^{-1}$, and in the spectral range of $4000-400 \mathrm{~cm}^{-1}$. For fluorescence analysis, the concentrations of HS were previously evaluated to eliminate the inner filter effect in solutions containing 5 , $10,15,20,25$, and $50 \mathrm{mg} \mathrm{L}^{-1}$ of total organic carbon (TOC). The concentrations were adjusted using a TOC analyzer (Shimadzu, TOC-VCSN, Japan); in which from the TOC values obtained of the stock solutions, dilutions were done to obtain the respective concentrations mentioned above. The best concentration was $10 \mathrm{mg} \mathrm{L}^{-1}$ for HS-ADE and HS-SR, so all the extracts were characterized in solutions of $10 \mathrm{mg} \mathrm{L}^{-1}$ of TOC prepared in $0.05 \mathrm{~mol} \mathrm{~L}^{-1}$ of $\mathrm{NaHCO}_{3}$ with apH of 8 . The fluorescence measurements were performed using a luminescence spectrometer (Thermo Scientific, Lumina, USA). The emission spectra were recorded in the range of 380-600 nm at a constant excitation wavelength $(360 \mathrm{~nm})$. Excitation-emission matrix (EEM) spectra were acquired through the emission wavelength range from 300 to $600 \mathrm{~nm}$ and the excitation wavelength range from 250 to $500 \mathrm{~nm}$ increasing sequentially by $5 \mathrm{~nm}$ with a scan speed of $1200 \mathrm{~nm} \mathrm{~min}{ }^{-1}$. The EEM graphics, which were plotted as contour maps from spectral data, were also treated using a mathematical method known as canonical polyadic/ parallel factor analysis (CP/PARAFAC). ${ }^{44-47} \mathrm{UV}$-Vis analyses was performed with $\mathrm{HS}$ solutions of $10.0 \mathrm{mg} \mathrm{L}^{-1}$ of TOC prepared in $\mathrm{NaHCO}_{3}\left(0.05 \mathrm{~mol} \mathrm{~L}^{-1}\right)$ and $\mathrm{pH}$ of 8.0 to obtain the $\mathrm{E}_{4} / \mathrm{E}_{6}$ ratio by the absorbance acquired at 465 and $665 \mathrm{~nm}$ as measured using a UV-Vis spectrophotometer (Shimadzu, UV-2600, Japan).

\section{Dissolved organic matter isolation and analyses}

DOM, which is also referred to as water soluble organic matter (WSOM), was extracted from each layer. The extraction procedure was performed with deionized water $(18 \mathrm{M} \Omega \mathrm{cm})$ in a $1: 10(\mathrm{~m} / \mathrm{v})$ soil/water ratio, at room temperature $\left(20{ }^{\circ} \mathrm{C}\right)$ during $16 \mathrm{~h}$ under agitation on a shaker table $(200 \mathrm{rpm})$, as performed by Jiang et al. ${ }^{48}$ The DOM was separated after centrifugation (4000 rpm) for $30 \mathrm{~min}$ and filtered using a glass microfiber filter of $0.45 \mu \mathrm{m}$ (Millipore, $47 \mathrm{~mm}$ diameter) to separate solids. TOC were measured in the DOM samples by identifying the difference between organic carbon and inorganic carbon using a TOC Analyzer (Shimadzu, TOC-VCSN, Japan). The concentration of DOM in each sample was adjusted to $10 \mathrm{mg} \mathrm{L}^{-1}$ of TOC and UV-Vis and fluorescence analyses were performed, as previously described for HS. From UV-Vis $\mathrm{E}_{4} / \mathrm{E}_{6}, \mathrm{E}_{2} / \mathrm{E}_{4}$ and $\mathrm{E}_{2} / \mathrm{E}_{6}$ ratios were obtained from the absorbance measured in $465 / 665 \mathrm{~nm}, 265 / 465 \mathrm{~nm}$, and $265 / 665 \mathrm{~nm}$, respectively, in a range of 200 to $800 \mathrm{~nm}$. The specific ultraviolet absorbance (SUVA) index was obtained by the absorbance in a $254 \mathrm{~nm}$ normalized per carbon concentration and the optical path of a cuvette $\left(1 \mathrm{mg} \mathrm{C}^{-1} \mathrm{~m}^{-1}\right)$.

\section{Results and Discussion}

\section{Soil layer characterization}

The ADE layers showed differences in $\mathrm{pH}$ in relation to the SR (Table S1, SI section); this difference was mainly due to the presence of ash containing basic salts such as calcium and magnesium oxides, which increased the ADE soil $\mathrm{pH} .{ }^{49}$ The higher $\mathrm{pH}$ also contributed to the nutrient resilience in the soil owing to their major solubility in acidic media.

The main elements present in the layers from the ADE soil and SR are shown in Figure 1. The top layer of the 
ADE soil $(0-20 \mathrm{~cm})$ presented greater concentrations of carbon and nutrients compared with those of the SR, while the deepest layer $(80-100 \mathrm{~cm})$ was the most similar to the SR layers. The iron and aluminum concentrations in ADE soils are usually lower because the anthropogenic soil has lower concentrations of iron/aluminum oxides of pedogenic origin (Table 1) owing to the higher OM input that has a dilution effect. Furthermore, the higher OM content causes disaggregation in soil minerals. For this reason, the potassium content was higher in all the SR layers and in the 80-100 cm ADE layer, which was probably due the presence of illite in this site and the lower OM content, which did not cause any disaggregation. ${ }^{50}$

The higher carbon concentration in the top ADE layer showed the contribution of anthropogenic action, whereas the OM input in the top SR layer was mainly from fresh litter. The ADE sites were pre-Columbian dwelling areas, and the higher nutrient content reflects the occupation and input of organic wastes. The elements present in these soils could have been derived from animal and human excretions, as well as from other organic and inorganic wastes. The concentrations of calcium and magnesium might have been higher in this soil owing to the insertion of ash mainly from vegetal tissues that are rich in these nutrients. ${ }^{10}$ In addition, other possible sources were bone tissues and human and animal tissues that contain a large amount of calcium and phosphorus.

Minerals play an important role in SOM stabilization. Extractions were performed to evaluate the poorly crystalline iron/aluminum $\left(\mathrm{Fe}_{\mathrm{o}} / \mathrm{Al}_{\mathrm{o}}\right)$, pedogenic iron/ aluminum hydro(oxides) $\left(\mathrm{Fe}_{\mathrm{d}} / \mathrm{Al}_{\mathrm{d}}\right)$, and iron/aluminum bonded to $\mathrm{SOM}\left(\mathrm{Fe}_{\mathrm{p}} / \mathrm{Al}_{\mathrm{p}}\right)$ to compare the differences between the studied soils. The results are reported in Table 1. The higher $\mathrm{Fe}_{\mathrm{o}}$ and $\mathrm{Al}_{\mathrm{o}}$ concentrations in the ADE layers showed the influence of $\mathrm{OM}$ on soil minerals. OM functional groups as well as aromatic moieties are effective binders to which iron/aluminum may be bound, thereby reducing crystallization. ${ }^{51}$ Therefore, the $\mathrm{Fe}_{\mathrm{d}}$ and $\mathrm{Al}_{\mathrm{d}}$ concentrations were lower in the ADE soil than in the $\mathrm{SR}$, and the values increased with depth because of the
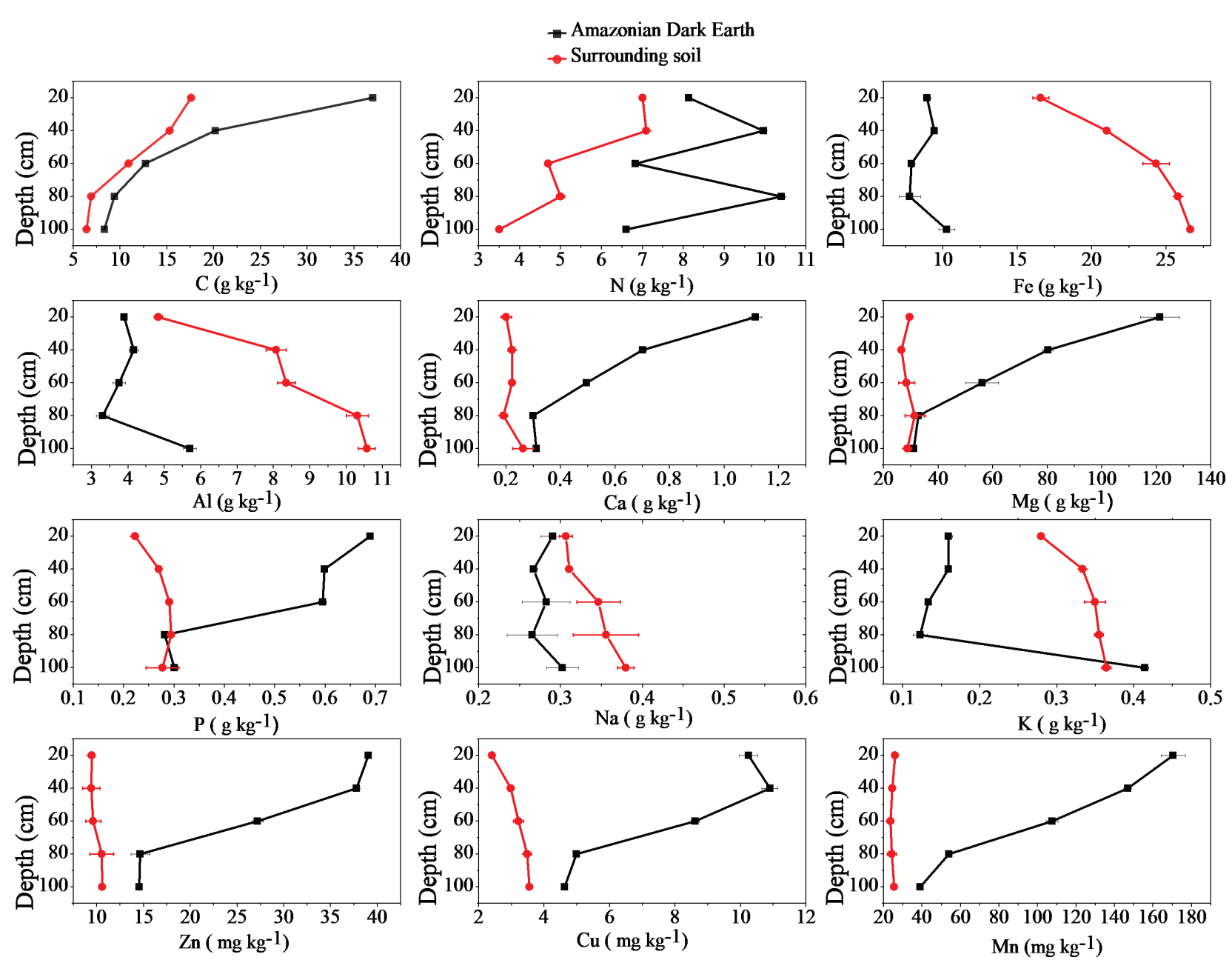

Figure 1. The concentrations of carbon, nitrogen, iron, aluminum, calcium, magnesium, phosphorus, sodium, potassium, zinc, copper, and manganese in the soil layers of Amazonian dark earth and surrounding soil. 
Table 1. Concentrations of iron and aluminum forms in the layers of Amazonian dark earth and surrounding soils

\begin{tabular}{|c|c|c|c|c|c|c|c|c|c|c|c|c|c|c|}
\hline & $\begin{array}{l}\text { Soil } \\
\text { layer / } \\
\mathrm{cm}\end{array}$ & $\begin{array}{c}\mathrm{Fe}_{\mathrm{o}} / \\
\left(\mathrm{g} \mathrm{kg}^{-1}\right)\end{array}$ & $\begin{array}{c}\mathrm{Fe}_{\mathrm{d}} / \\
\left(\mathrm{g} \mathrm{kg}^{-1}\right)\end{array}$ & $\begin{array}{c}\mathrm{Fe}_{\mathrm{p}} / \\
\left(\mathrm{g} \mathrm{kg}^{-1}\right)\end{array}$ & $\begin{array}{c}\mathrm{Fe}_{\text {tot }} / \\
\left(\mathrm{g} \mathrm{kg}^{-1}\right)\end{array}$ & $\mathrm{Fe}_{\mathrm{d}} / \mathrm{Fe}_{\mathrm{tot}}$ & $\mathrm{Fe}_{\mathrm{o}} / \mathrm{Fe}_{\mathrm{d}}$ & $\begin{array}{c}\mathrm{Al}_{\mathrm{o}} / \\
\left(\mathrm{g} \mathrm{kg}^{-1}\right)\end{array}$ & $\begin{array}{c}\mathrm{Al}_{\mathrm{d}} / \\
\left(\mathrm{g} \mathrm{kg}^{-1}\right)\end{array}$ & $\begin{array}{c}\mathrm{Al}_{\mathrm{p}} / \\
\left(\mathrm{g} \mathrm{kg}^{-1}\right)\end{array}$ & $\begin{array}{c}\mathrm{Al}_{\mathrm{tot}} / \\
\left(\mathrm{g} \mathrm{kg}^{-1}\right)\end{array}$ & $\mathrm{Al}_{\mathrm{d}} / \mathrm{Al}_{\mathrm{tot}}$ & $\mathrm{Al}_{\mathrm{o}} / \mathrm{Al}_{\mathrm{d}}$ & $\mathrm{Fe}_{\mathrm{p}}+\mathrm{Al}_{\mathrm{p}}$ \\
\hline \multirow{5}{*}{$\begin{array}{l}\text { Amazonian } \\
\text { dark earth }\end{array}$} & $0-20$ & $\begin{array}{c}0.38 \pm \\
0.01\end{array}$ & $\begin{array}{c}6.71 \pm \\
0.27\end{array}$ & $\begin{array}{c}0.70 \pm \\
0.04\end{array}$ & $\begin{array}{c}8.94 \pm \\
0.24\end{array}$ & 0.75 & 0.050 & $\begin{array}{c}1.07 \pm \\
0.01\end{array}$ & $\begin{array}{c}2.28 \pm \\
0.08\end{array}$ & $\begin{array}{c}0.57 \pm \\
0.07\end{array}$ & $\begin{array}{c}3.89 \pm \\
0.04\end{array}$ & 0.58 & 0.47 & $\begin{array}{c}1.27 \pm \\
0.08\end{array}$ \\
\hline & $20-40$ & $\begin{array}{c}0.43 \pm \\
0.05\end{array}$ & $\begin{array}{c}6.23 \pm \\
0.35\end{array}$ & $\begin{array}{c}0.44 \pm \\
0.01\end{array}$ & $\begin{array}{c}9.40 \pm \\
0.11\end{array}$ & 0.66 & 0.070 & $\begin{array}{c}1.45 \pm \\
0.17\end{array}$ & $\begin{array}{c}2.59 \pm \\
0.10\end{array}$ & $\begin{array}{c}0.70 \pm \\
0.05\end{array}$ & $\begin{array}{c}4.15 \pm \\
0.12\end{array}$ & 0.62 & 0.56 & $\begin{array}{c}1.15 \pm \\
0.05\end{array}$ \\
\hline & $40-60$ & $\begin{array}{c}0.35 \pm \\
0.02\end{array}$ & $\begin{array}{c}5.66 \pm \\
0.25\end{array}$ & $\begin{array}{c}0.44 \pm \\
0.10\end{array}$ & $\begin{array}{c}7.81 \pm \\
0.21\end{array}$ & 0.72 & 0.060 & $\begin{array}{c}1.32 \pm \\
0.01\end{array}$ & $\begin{array}{c}2.40 \pm \\
0.15\end{array}$ & $\begin{array}{c}0.55 \pm \\
0.01\end{array}$ & $\begin{array}{c}3.75 \pm \\
0.17\end{array}$ & 0.64 & 0.55 & $\begin{array}{c}1.00 \pm \\
0.10\end{array}$ \\
\hline & $60-80$ & $\begin{array}{c}0.24 \pm \\
0.01\end{array}$ & $\begin{array}{c}5.47 \pm \\
0.20\end{array}$ & $\begin{array}{c}0.39 \pm \\
0.14\end{array}$ & $\begin{array}{c}8.07 \pm \\
0.71\end{array}$ & 0.68 & 0.040 & $\begin{array}{c}0.61 \pm \\
0.03\end{array}$ & $\begin{array}{c}1.62 \pm \\
0.10\end{array}$ & $\begin{array}{c}0.18 \pm \\
0.01\end{array}$ & $\begin{array}{c}3.30 \pm \\
0.17\end{array}$ & 0.49 & 0.37 & $\begin{array}{c}0.58 \pm \\
0.14\end{array}$ \\
\hline & $80-100$ & $\begin{array}{c}0.26 \pm \\
0.02 \\
\end{array}$ & $\begin{array}{c}8.63 \pm \\
0.88 \\
\end{array}$ & $\begin{array}{c}0.46 \pm \\
0.01 \\
\end{array}$ & $\begin{array}{c}8.79 \pm \\
0.54 \\
\end{array}$ & 0.98 & 0.030 & $\begin{array}{c}0.47 \pm \\
0.01 \\
\end{array}$ & $\begin{array}{c}2.21 \pm \\
0.18 \\
\end{array}$ & $\begin{array}{c}0.11 \pm \\
0.01 \\
\end{array}$ & $\begin{array}{c}5.70 \pm \\
0.17 \\
\end{array}$ & 0.38 & 0.21 & $\begin{array}{c}0.57 \pm \\
0.01 \\
\end{array}$ \\
\hline \multirow{5}{*}{$\begin{array}{l}\text { Surrounding } \\
\text { soil }\end{array}$} & $0-20$ & $\begin{array}{c}0.22 \pm \\
0.02\end{array}$ & $\begin{array}{c}11.58 \pm \\
0.27\end{array}$ & $\begin{array}{c}0.62 \pm \\
0.02\end{array}$ & $\begin{array}{c}15.06 \pm \\
0.54\end{array}$ & 0.76 & 0.019 & $\begin{array}{c}0.65 \pm \\
0.11\end{array}$ & $\begin{array}{c}2.96 \pm \\
0.06\end{array}$ & $\begin{array}{c}0.19 \pm \\
0.01\end{array}$ & $\begin{array}{c}4.83 \pm \\
0.11\end{array}$ & 0.61 & 0.22 & $\begin{array}{c}0.82 \pm \\
0.02\end{array}$ \\
\hline & $20-40$ & $\begin{array}{c}0.22 \pm \\
0.03\end{array}$ & $\begin{array}{c}15.12 \pm \\
0.35\end{array}$ & $\begin{array}{c}0.54 \pm \\
0.05\end{array}$ & $\begin{array}{c}21.11 \pm \\
0.19\end{array}$ & 0.71 & 0.014 & $\begin{array}{c}0.84 \pm \\
0.20\end{array}$ & $\begin{array}{c}3.81 \pm \\
0.17\end{array}$ & $\begin{array}{c}0.19 \pm \\
0.01\end{array}$ & $\begin{array}{c}8.07 \pm \\
0.27\end{array}$ & 0.47 & 0.22 & $\begin{array}{c}0.74 \pm \\
0.05\end{array}$ \\
\hline & $40-60$ & $\begin{array}{c}0.18 \pm \\
0.01\end{array}$ & $\begin{array}{c}17.63 \pm \\
0.24\end{array}$ & $\begin{array}{l}0.46 \pm \\
0.05\end{array}$ & $\begin{array}{c}24.78 \pm \\
0.89\end{array}$ & 0.71 & 0.010 & $\begin{array}{c}0.71 \pm \\
0.01\end{array}$ & $\begin{array}{c}4.28 \pm \\
0.01\end{array}$ & $\begin{array}{c}0.19 \pm \\
0.01\end{array}$ & $\begin{array}{c}8.35 \pm \\
0.24\end{array}$ & 0.51 & 0.16 & $\begin{array}{l}0.67 \pm \\
0.05\end{array}$ \\
\hline & $60-80$ & $\begin{array}{c}0.16 \pm \\
0.01\end{array}$ & $\begin{array}{c}18.62 \pm \\
0.20\end{array}$ & $\begin{array}{c}0.38 \pm \\
0.11\end{array}$ & $\begin{array}{c}25.73 \pm \\
0.24\end{array}$ & 0.73 & 0.008 & $\begin{array}{c}0.67 \pm \\
0.01\end{array}$ & $\begin{array}{c}4.38 \pm \\
0.27\end{array}$ & $\begin{array}{c}0.16 \pm \\
0.02\end{array}$ & $\begin{array}{c}10.30 \pm \\
0.30\end{array}$ & 0.42 & 0.15 & $\begin{array}{c}0.55 \pm \\
0.02\end{array}$ \\
\hline & $80-100$ & $\begin{array}{c}0.16 \pm \\
0.02\end{array}$ & $\begin{array}{c}19.37 \pm \\
0.88\end{array}$ & $\begin{array}{c}0.50 \pm \\
0.01\end{array}$ & $\begin{array}{c}28.97 \pm \\
0.14\end{array}$ & 0.67 & 0.008 & $\begin{array}{c}0.61 \pm \\
0.01\end{array}$ & $\begin{array}{c}4.50 \pm \\
0.37\end{array}$ & $\begin{array}{c}0.14 \pm \\
0.01\end{array}$ & $\begin{array}{c}10.56 \pm \\
0.23\end{array}$ & 0.42 & 0.13 & $\begin{array}{c}0.64 \pm \\
0.01\end{array}$ \\
\hline
\end{tabular}

$\mathrm{Fe}_{\mathrm{o}} / \mathrm{Al}_{\mathrm{o}}$ : iron/aluminum concentration of amorphous oxides; $\mathrm{Fe}_{\mathrm{d}} / \mathrm{Al}_{\mathrm{d}}$ : iron/aluminum concentration of pedogenic oxides; $\mathrm{Fe}_{\mathrm{p}} / \mathrm{Al}_{\mathrm{p}}$ : iron/aluminum concentration bonded to soil organic matter $(\mathrm{SOM}) ; \mathrm{Fe}_{\mathrm{tol}} / \mathrm{Al}_{\text {tol }}$ : total concentration of iron/aluminum; $\mathrm{Fe}_{\mathrm{p}}+\mathrm{Al}_{\mathrm{p}}$ : total iron and aluminum bonded to SOM.

higher content of iron/aluminum oxides. The $80-100 \mathrm{~cm}$ ADE layer had the highest iron concentration from oxides (ratio of $\mathrm{Fe}_{\mathrm{d}} / \mathrm{Fe}_{\mathrm{tot}}$ ), thereby suggesting a transition between the anthropogenic soil and the soil of the region.

The iron bound to $\mathrm{SOM}\left(\mathrm{Fe}_{\mathrm{p}}\right)$ was similar in both soils, whereas the $\mathrm{Al}_{\mathrm{p}}$ content in the $\mathrm{ADE}$ soil was 3 times higher than that in the SR, thereby showing that the SOM present in $\mathrm{ADE}$ (depth of 0 to $60 \mathrm{~cm}$ ) has a preference for binding aluminum rather than iron. The preference is probably due to the OM arrangement, which is more humified in ADE than that in SR and is comprised of both aromatic and oxygenated groups (which generate electrostatic interactions). ${ }^{52}$ The ratio values of $\mathrm{Fe}_{\mathrm{o}} / \mathrm{Fe}_{\mathrm{d}}$ and $\mathrm{Al}_{\mathrm{o}} / \mathrm{Al}_{\mathrm{d}}$ were larger for the ADE soils than for the SR, which showed that the iron and aluminum oxides present in the ADE had less crystallinity compared to those in the SR. In the SR, there was a prevalence of crystalline iron oxides (ratio of $\mathrm{Fe}_{\mathrm{o}} / \mathrm{Fe}_{\mathrm{d}}$ lower than 0.04 ), which are typical of weathered tropical soils such as Oxisols. ${ }^{53} \mathrm{Al}_{\mathrm{o}}$ and $\mathrm{Al}_{\mathrm{p}}$ showed a higher linear correlation $(r=0.91)$ see Figure $S 2$, in the SI section, thereby suggesting that poorly crystalline aluminum was the form bound to the SOM from the ADE. These results suggested that poorly crystalline aluminum oxides are more effective in organo-mineral interaction than ordered oxides $\left(\mathrm{Al}_{\mathrm{d}}\right)$.

The total iron and aluminum bound to $\operatorname{SOM}\left(\mathrm{Fe}_{\mathrm{p}}+\mathrm{Al}_{\mathrm{p}}\right)$ is useful for measuring the total organo-mineral interactions of iron and aluminum. The SOM from ADE had a higher mineral protection than the SOM of the SR (Table 1). The SOM bonded to iron and aluminum generates physical protection owing to the formation of aggregates that prevent microbial degradation. ${ }^{54}$ The physical-chemical mechanism of SOM protection is unclear (under discussion); ${ }^{55-58}$ however, it is known that the OM accumulation in soil is the result of microbiologically restricted access due to the adsorption or incorporation of minerals or even the incorporation of particles of different size distributions into aggregates, thereby resulting in physical protection that blocks the access of microorganisms. ${ }^{23,59}$ These results suggested that the minerals had some degree of importance to ADE SOM stabilization, which is important for carbon sequestration. Furthermore, in addition to minerals generating SOM protection, the nutrients bound to SOM may also play an import role in its stabilization, such as Nebbioso and Piccolo ${ }^{60}$ pointed out that the calcium bonded to SOM increased its molecular rigidity.

Chemical and spectroscopic characterization of humic substances

The FTIR spectra of HS from the ADE and SR are shown in Figure S3 (SI section). In all the spectra, the band positioned around $3300 \mathrm{~cm}^{-1}$ was ascribed to $\mathrm{O}-\mathrm{H}$ stretching modes, which can be associated with alcohols, 
phenols, and carboxylic acids. This band was also ascribed to $\mathrm{N}-\mathrm{H}$ stretching of amines and amides. It was possible to observe a more intense band at $3300 \mathrm{~cm}^{-1}$ in the top layer of HS-ADE than in the deeper fractions. For HS-SR, this same band was observed in the second layer $(20-40 \mathrm{~cm})$ and last layer $(80-100 \mathrm{~cm})$. The small band at $2923 \mathrm{~cm}^{-1}$ present in HS-ADE in the top layer could have been correlated to $-\mathrm{CH}_{2}$ groups; these groups were absent in the deeper fractions, thereby suggesting a mixture of fresh OM input and pyrogenic OM. In HS-SR, the bands positioned around 2917 and $2850 \mathrm{~cm}^{-1}$ were ascribed to asymmetric and symmetric $\mathrm{C}-\mathrm{H}$ stretching modes that were present in all the HS-SR layers. These modes demonstrated that the arrangement of HS-SR contained more aliphatic moieties, such as fatty acids from plant waxes and polyesters, when compared with that of HS-ADE, which did not present these bands. The band around $1710 \mathrm{~cm}^{-1}$ in both HS-ADE and HS-SR was correlated with $\mathrm{C}=\mathrm{O}$ stretching modes of various carbonyl groups (mainly of carboxylic acids), and the band around $1600 \mathrm{~cm}^{-1}$ was attributed to $\mathrm{C}=\mathrm{C}$ in aromatic rings. The band around $1420 \mathrm{~cm}^{-1}$ with a small shoulder around $1387 \mathrm{~cm}^{-1}$ was also correlated with the $\mathrm{C}-\mathrm{H}$ bending mode of aliphatic compounds. Between the region of 1300 to $1000 \mathrm{~cm}^{-1}, \mathrm{C}-\mathrm{O}$ stretching vibrations occurred. The band around $1238 \mathrm{~cm}^{-1}$ was correlated with $\mathrm{O}-\mathrm{H}$ bending of carboxylic and phenol compounds. There was possible contribution of $\mathrm{Si}-\mathrm{O}$ stretching at $1030 \mathrm{~cm}^{-1}$ owing to the impurities caused by the interaction of the HS with silicates. ${ }^{34}$

The thermogravimetric analysis (TGA) and derivative thermogravimetric (DTG) curves of HS-ADE and HS-SR are shown in Figure S4. In general, for both HS, the TGA curves exhibited two weight loss events; the first (around $300{ }^{\circ} \mathrm{C}$ ) was correlated with the loss of compounds with oxygenated functional groups, aliphatic structures, and peptides, and the second $\left(400-500^{\circ} \mathrm{C}\right)$ was correlated with the destruction of aromatic moieties. ${ }^{43}$ The DTG curves of HS-ADE showed an intense second peak, and the top layer experienced the greatest weight loss correlated with the degradation of aromatic moieties, thereby suggesting an arrangement with more aromaticity than that of the other deeper layers. Furthermore, the largest presence of metal ions (from soil minerals and nutrients) in HS-ADE might have generated a more thermodynamically stable arrangement, thereby shifting the degradation to higher temperatures. HSSR showed less weight loss related to aromatic moieties and more related to aliphatic structures compared with HS-ADE, thereby suggesting a different conformational arrangement and thermic stability between the HS.

The elemental compositions, $\mathrm{H} / \mathrm{C}, \mathrm{C} / \mathrm{N}, \mathrm{H} / \mathrm{O}$, and $\mathrm{O} / \mathrm{C}$ atomic ratios, and $\mathrm{E}_{4} / \mathrm{E}_{6}$ ratios are reported in Table 2. The results of the elemental analyses showed that the top layer had the highest concentrations of carbon, hydrogen, and nitrogen in both HS. The oxygen content was almost the same for all fractions of ADE, while in the SR there was a difference of $24.4 \%$ in oxygen between the top layer and the bottom layer. The $\mathrm{O} / \mathrm{C}$ atomic ratio allowed us to estimate the abundance of oxygen groups, ${ }^{61}$ which indicated that HS-ADE had less oxygen groups in the top layer; the SR presented the opposite trend. The $\mathrm{H} / \mathrm{O}$ atomic ratio is used as an index of OM oxidation; a lower $\mathrm{H} / \mathrm{O}$ atomic ratio suggests that the molecules have more oxygen groups and that it is more polar than hydrophobic. ${ }^{62}$ Based on this ratio, HS-ADE is more hydrophobic than polar in the top layer, while HS-SR presented the opposite trend. The $\mathrm{H} / \mathrm{C}$ atomic ratio and $\mathrm{E}_{4} / \mathrm{E}_{6}$ ratio increased for HS-ADE in the deeper layers. In contrast, these ratios decreased for HS-SR in the deeper layers. These results showed that HS from the top layer have greater aromaticity than those in the deeper layers for ADE soil, whereas HS-SR had the greatest aromaticity in the deepest layer (lower $\mathrm{H} / \mathrm{C}$ and $\mathrm{E}_{4} / \mathrm{E}_{6}$ ratios).

The H/C, H/O, and O/C atomic ratios suggested that HS-ADE of the top layer presented a more complex structure with an extended aromatic ring and comprised more hydrophobic than polar moieties, and this trend changed with depth. HS-SR presented an arrangement comprised of small molecules rich in aliphatic structures with more oxygen groups as well as more polar than hydrophobic compounds; in depth, the HS-SR was more aromatic and more hydrophobic in deeper layers. The elemental analysis showed that the anthropogenic action changed the OM features in depth in relation to SR. The accumulation of the most hydrophobic moieties in depth in the SR is a result of the greater thermodynamic stability caused by apolar interactions, ${ }^{52}$ as well as organo-mineral interactions and microbial inaccessibility.

Figure 2 shows the fluorescence emission spectra of HS extracted from the ADE (Figure 2a) and SR (Figure 2b) soil layers. The maximum fluorescence intensity (FI) was in the range of 472 to $488 \mathrm{~nm}$. HS-ADE extracted from the $0-20 \mathrm{~cm}$ layer presented the lowest FI in relation to the other soil fractions. The lowest FI could have been associated with linearly aromatic ring systems. ${ }^{63}$ The HS-ADE extracted from the top layer also presented the most intense red-shift peak $(502 \mathrm{~nm})$ in relation to that extracted from deeper layers $(486 \mathrm{~nm})$. This behavior suggested that the HS in the top layer presented an arrangement that was mainly composed of aromatic moieties. Humic substancessurrounding soils showed a blue shift $(476 \mathrm{~nm})$, while in the $40-60 \mathrm{~cm}$ and $60-80 \mathrm{~cm}$ layers, they presented a red shift of $10 \mathrm{~nm}$ (around $488 \mathrm{~nm}$ ). It was still possible to observe 
Table 2. Elemental composition, atomic ratios, and $\mathrm{E}_{4} / \mathrm{E}_{6}$ ratios of the humic substances extracted from different layers at various depths in Amazonian dark earth soil and surrounding soil

\begin{tabular}{|c|c|c|c|c|c|c|c|c|c|c|}
\hline & Layer / cm & $\mathrm{C} / \%$ & $\mathrm{H} / \%$ & $\mathrm{~N} / \%$ & $\mathrm{O} / \%$ & $\mathrm{H} / \mathrm{C}$ & $\mathrm{C} / \mathrm{N}$ & $\mathrm{O} / \mathrm{C}$ & $\mathrm{H} / \mathrm{O}$ & $\mathrm{E}_{4} / \mathrm{E}_{6}$ \\
\hline \multirow{5}{*}{$\begin{array}{l}\text { Amazonian dark } \\
\text { earth }\end{array}$} & $0-20$ & $52.07 \pm 0.07$ & $5.10 \pm 0.01$ & $3.63 \pm 0.04$ & $39.20 \pm 0.10$ & 1.17 & 16.82 & 0.57 & 2.07 & 4.35 \\
\hline & $20-40$ & $53.96 \pm 0.15$ & $5.64 \pm 0.11$ & $3.05 \pm 0.03$ & $37.35 \pm 0.30$ & 1.25 & 20.74 & 0.52 & 2.40 & 3.76 \\
\hline & $40-60$ & $51.75 \pm 0.13$ & $5.10 \pm 0.02$ & $2.57 \pm 0.01$ & $40.57 \pm 0.12$ & 1.18 & 23.61 & 0.59 & 2.00 & 3.85 \\
\hline & $60-80$ & $47.59 \pm 0.09$ & $4.98 \pm 0.06$ & $2.23 \pm 0.01$ & $45.19 \pm 0.03$ & 1.25 & 24.95 & 0.71 & 1.75 & 3.89 \\
\hline & $80-100$ & $43.22 \pm 0.08$ & $5.82 \pm 0.08$ & $2.33 \pm 0.01$ & $48.63 \pm 0.18$ & 1.60 & 21.75 & 0.84 & 1.90 & 4.23 \\
\hline \multirow{5}{*}{ Surrounding soil } & $0-20$ & $44.50 \pm 0.04$ & $5.66 \pm 0.01$ & $2.89 \pm 0.05$ & $49.96 \pm 0.01$ & 1.51 & 18.06 & 0.79 & 1.91 & 4.29 \\
\hline & $20-40$ & $45.38 \pm 0.16$ & $5.59 \pm 0.01$ & $2.62 \pm 0.02$ & $46.41 \pm 0.15$ & 1.47 & 20.30 & 0.77 & 1.91 & 3.69 \\
\hline & $40-60$ & $53.21 \pm 0.04$ & $6.70 \pm 0.08$ & $2.80 \pm 0.01$ & $37.29 \pm 0.11$ & 1.49 & 22.13 & 0.63 & 1.00 & 3.62 \\
\hline & $60-80$ & $47.22 \pm 0.06$ & $5.86 \pm 0.06$ & $2.43 \pm 0.01$ & $44.48 \pm 0.01$ & 1.47 & 22.61 & 0.57 & 1.10 & 3.61 \\
\hline & $80-100$ & $63.99 \pm 0.04$ & $7.07 \pm 0.02$ & $3.22 \pm 0.01$ & $25.72 \pm 0.01$ & 1.31 & 23.16 & 0.91 & 0.70 & 3.73 \\
\hline
\end{tabular}

that HS-SR had a FI of approximately 2 times greater than that of the HS of ADE soils.

The EEM of both HS (Figure S5, SI section) showed the presence of the same two fluorophores at excitation/ emission wavelength pairs of 458-465/530-539 and 300-308/494-520. The CP-PARAFAC also suggested two components on the sample with the core consistency diagnostic (CORCONDIA) of $96.4 \%$, as shown in Figure $3 .{ }^{64}$ Component 1 (C1) ( $\lambda$ ex/ $\left./ \mathrm{em}: 300 / 475\right)$ and component 2 (C2) $(\lambda \mathrm{ex} / \lambda \mathrm{em}: 475 / 530)$ was assigned to humic-like acid such as humic acid of soil, because both are shifted to red. However, the $\mathrm{C} 2$ was more red shifted that suggested a more aromatic arrangement or molecular aggregation than $\mathrm{C}$.

Figure 4 shows the variation of the FI of the components in the ADE (Figure 4a) and SR (Figure 4b) soil layers. For ADE, the FI of both components increased with depth, thereby suggesting a greater amount of substituents such as hydroxyl, methoxy, and amino groups in a less aromatic domain (shorter wavelengths), which could increase the FI (corroborating with a decreased $\mathrm{H} / \mathrm{C}$ ratio (Table 2) and the intensity of peak 2 in DTG correlated with aromatic moieties (Figure S4, SI section)). HS-SR presented the greatest intensity in the top layer and the FI decreased with depth, thereby suggesting a low degree of aromaticity, low molecular weight, and the presence of electron-donating substituents in the top layer. ${ }^{34,63,65}$ The fluorescence results were in agreement with the $\mathrm{H} / \mathrm{O}, \mathrm{O} / \mathrm{C}$, and $\mathrm{C} / \mathrm{N}$ ratios of HS-SR, which suggested the presence of more oxygen and nitrogen in the top layer.

The HS-ADE presented a more complex structure on the top layer, which was probably because this layer suffered from anthropogenic action and was more impacted. HS-ADE from the depth between 20 and $80 \mathrm{~cm}$ seemed to have the same structural arrangement, while the deeper fraction $(80-100 \mathrm{~cm})$ showed a transition to the local soil. Humic substances-surrounding soils presented more aliphatic moieties mainly in the top layer from the deposition of fresh litter. As the SOM decomposed into smaller molecules, these molecules migrated deeper until
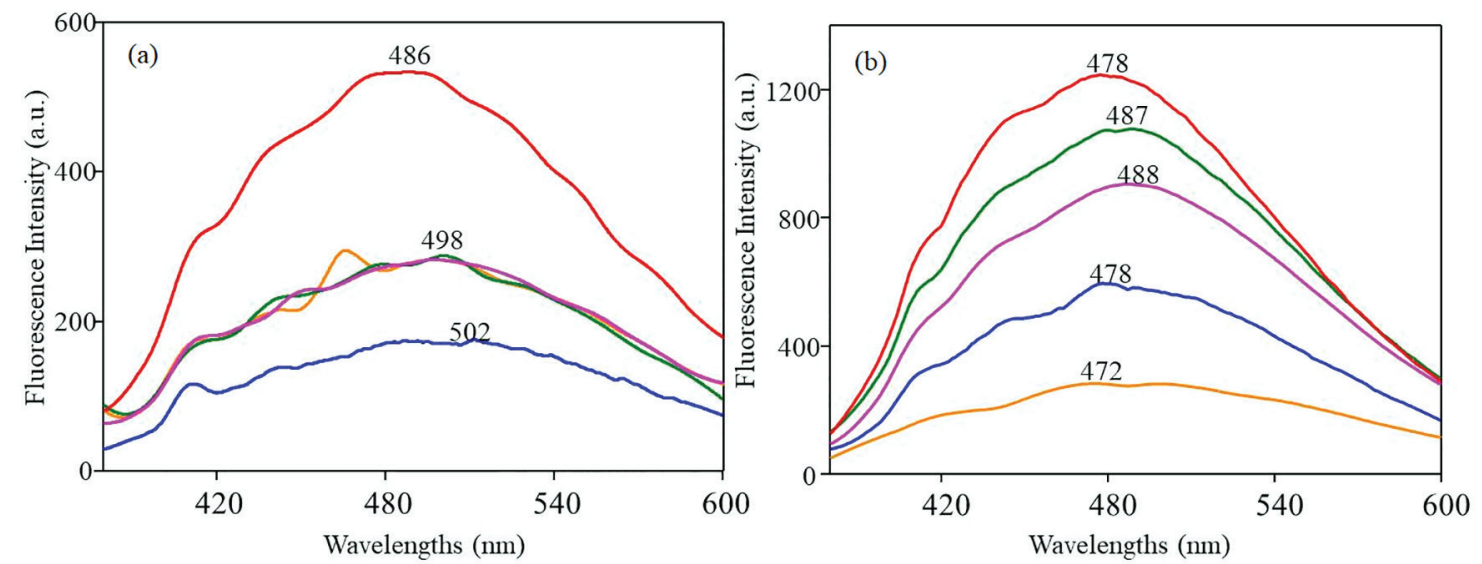

Figure 2. Fluorescence emission spectra of soil layers of (-) 0-20 cm, (-) 20-40 cm, (-) 40-60 cm, (-) 60-80 cm, and (-) 80-100 cm in Amazonian dark earth (a) and surrounding soil (b). $\lambda$ excitation: $360 \mathrm{~nm}$. 


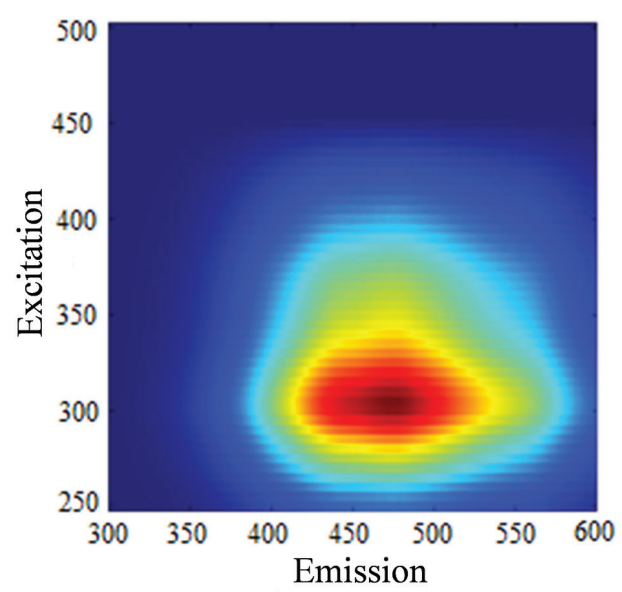

(a) Component 1

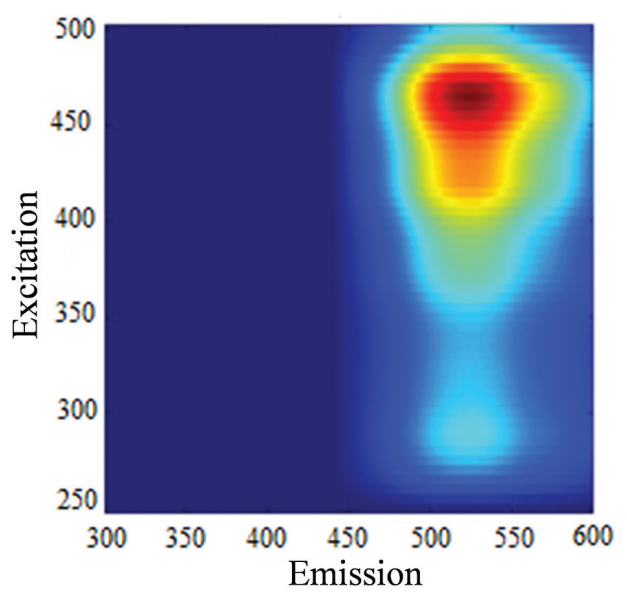

(b) Component 2

Figure 3. Component 1 (a) and component 2 (b) identified through canonical polyadic/parallel factor analysis (CP/PARAFAC) in the excitation-emission matrixes fluorescence spectra of humic substances from both soils (Amazonian dark earth and surrounding soil).
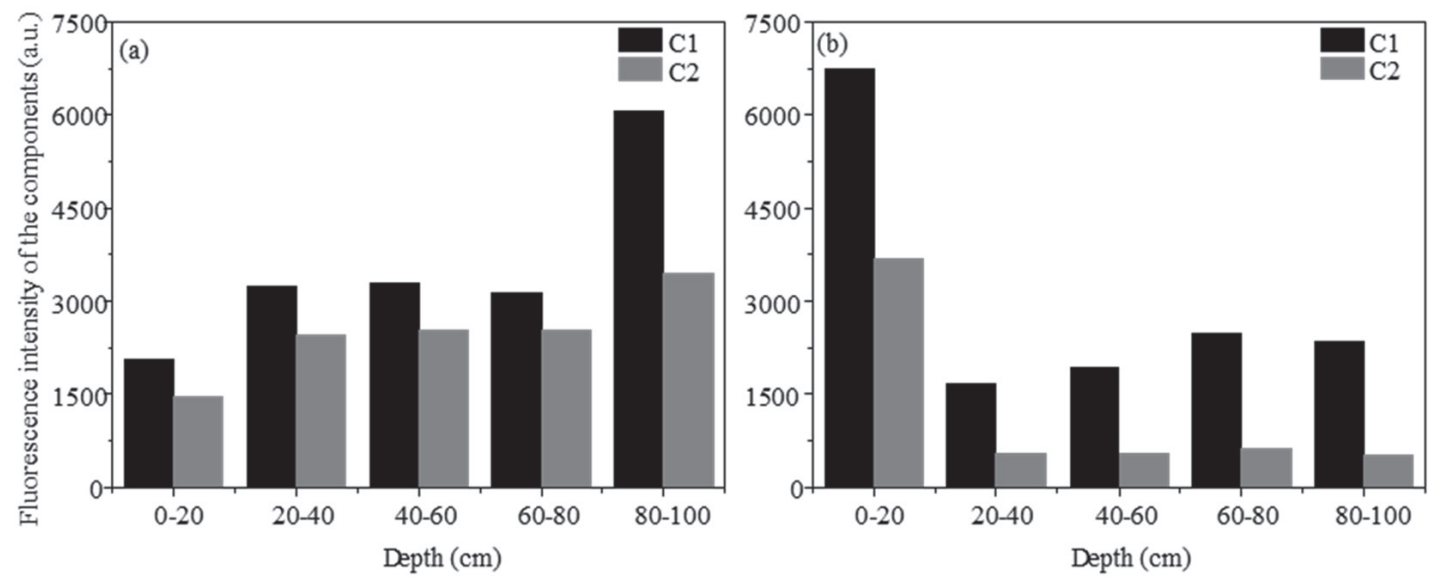

Figure 4. Fluorescence intensity contribution of component $1(\mathrm{C} 1)$ and component $(\mathrm{C} 2)$ identified through canonical polyadic/parallel factor analysis (CP/PARAFAC) in the fluorescence excitation-emission matrixes of (a) humic substances from Amazonian dark earth and (b) humic substances from surrounding soils at different depths.

they were stabilized by their hydrophobic nature and mineral interaction.

\section{Characterization of the dissolved organic matter}

Table 3 shows that the SR layers contained more DOM than the ADE soil owing to the greater extraction of TOC. The lower TOC values for the DOM from the ADE compared with those of the SR suggested that the SOM from the ADE was less soluble, which was probably owing to its hydrophobic nature. In addition, it suggested that the SR contained more readily available OM than ADE. The $E_{4} / E_{6}$ and $E_{2} / E_{6}$ ratios were correlated with the polycondensation degree of aromatic moieties; the increase in the ratios downward in the ADE soil might have been due the simple units of DOM, while the first layer with low ratios had a higher polycondensation degree of aromatic units. The same trend was observed for the SR. The increase in the $\mathrm{E}_{2} / \mathrm{E}_{4}$ ratio downward suggested the degradation of SOM into simpler aromatic moieties ${ }^{66}$ thereby showing that the DOM from SR was composed of small molecules. The highest values of the 254 and SUVA indexes in deeper layers also suggested less aromatic domain. Comparing both soils, all the indexes suggested that the superficial fraction had an aromatic arrangement, and thus decreased as the depth increased.

The SOM decomposition into simpler structures facilitated their percolation to the deeper layers. Both deeper layers (40-60 and 60-80 cm) from the SR presented higher contents of TOC because the DOM percolated from the fresh litter; the percolated DOM might have undergone stabilization in these fractions because of the higher clay content (Table S1). Furthermore, the HS-SR is more hydrophilic on top layer, which makes the DOM-aromatics (hydrophobic) percolate more easily and aggregate in the humic suprastructures in depth that are hydrophobic 
Table 3. Total organic carbon (TOC) and UV-Vis ratios/indexes $\left(\mathrm{E}_{4} / \mathrm{E}_{6}, \mathrm{E}_{2} / \mathrm{E}_{4}, \mathrm{E}_{2} / \mathrm{E}_{6}, 254\right.$, and SUVA) of the dissolved organic matter extracted from different layers in Amazonian dark earth and surrounding soil

\begin{tabular}{|c|c|c|c|c|c|c|c|}
\hline & Layer / cm & $\mathrm{TOC} /\left(\mathrm{mg} \mathrm{L}^{-1}\right)$ & $\mathrm{E}_{4} / \mathrm{E}_{6}$ & $\mathrm{E}_{2} / \mathrm{E}_{4}$ & $\mathrm{E}_{2} / \mathrm{E}_{6}$ & 254 & SUVA \\
\hline \multirow{5}{*}{ Amazonian dark earth } & $0-20$ & 28.51 & 3.85 & 6.81 & 26.25 & 3.23 & 11.34 \\
\hline & $20-40$ & 25.86 & 5.23 & 8.85 & 46.38 & 1.67 & 6.46 \\
\hline & $40-60$ & 33.79 & 5.50 & 9.26 & 50.97 & 1.93 & 5.73 \\
\hline & $60-80$ & 25.45 & 6.09 & 9.87 & 60.19 & 1.96 & 7.71 \\
\hline & $80-100$ & 24.11 & 4.70 & 7.92 & 37.26 & 2.63 & 10.93 \\
\hline \multirow{5}{*}{ Surrounding soil } & $0-20$ & 35.66 & 3.79 & 6.51 & 24.70 & 0.63 & 1.77 \\
\hline & $20-40$ & 38.07 & 3.94 & 6.29 & 24.87 & 1.03 & 2.71 \\
\hline & $40-60$ & 44.30 & 4.42 & 7.36 & 32.59 & 1.45 & 3.28 \\
\hline & $60-80$ & 40.32 & 5.60 & 10.52 & 59.00 & 1.74 & 4.32 \\
\hline & $80-100$ & 28.72 & 6.04 & 11.77 & 71.17 & 1.72 & 5.98 \\
\hline
\end{tabular}

SUVA: specific ultraviolet absorbance.

(through apolar associations), in which increased the aromaticity of HS-SR in depth (Table 2).

The CP-PARAFAC suggested that there were two fluorescent components in the DOM from both soils (CORCONDIA of 90.7\%), as shown in Figure 5. C1 ( $\lambda$ ex/ $/$ em: $370 / 425)$ was correlated with simpler structures (excitation and emission at low wavelengths, i.e., blue shift), while C2 ( $\lambda$ ex/ $/ \mathrm{em}$ : $450 / 475)$ was correlated with more complex moieties, such as humic-like acid from the soil (excitation and emission at longer wavelengths, i.e., red shift). Tadini et al. ${ }^{67}$ verified the presence of the same components with PARAFAC in the humin from Amazonian soils.

The identified components in the DOM from ADE (Figure 6a) presented an opposite behavior, in which the FI of $\mathrm{C} 1$ decreased with depth while the FI of $\mathrm{C} 2$ increased with depth. The DOM from the top layer had a more

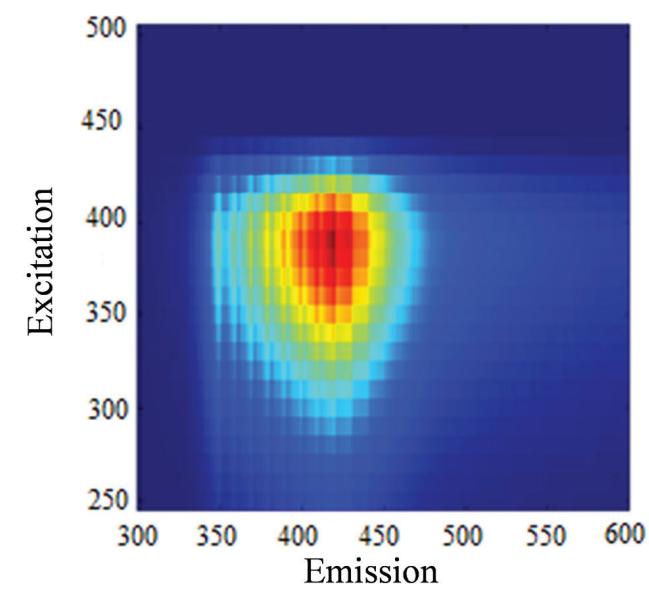

(a) Component 1 aromatic arrangement, and $\mathrm{C} 2$ was responsible for the complex structure. C2 presented less FI in the top layer, thereby suggesting a greater polycondensation degree of these structures. In contrast, the FI increased with depth, thereby suggesting a lesser polycondensation degree of these structures and more electron-donating substituents. ${ }^{63}$ C1 of SOM from the SR presented a more homogeneous intensity in all layers (Figure 6b). The increase in FI for $\mathrm{C} 2$ in the last layers suggested a structural arrangement of small molecules with substituents that enhanced the FI.

Features of soil organic matter composition

The SOM from ADE showed mainly hydrophobic characteristics as evidenced by the HS elemental analyses and the TOC of DOM. This intrinsic characteristic may be caused by fire in the management of the forest and

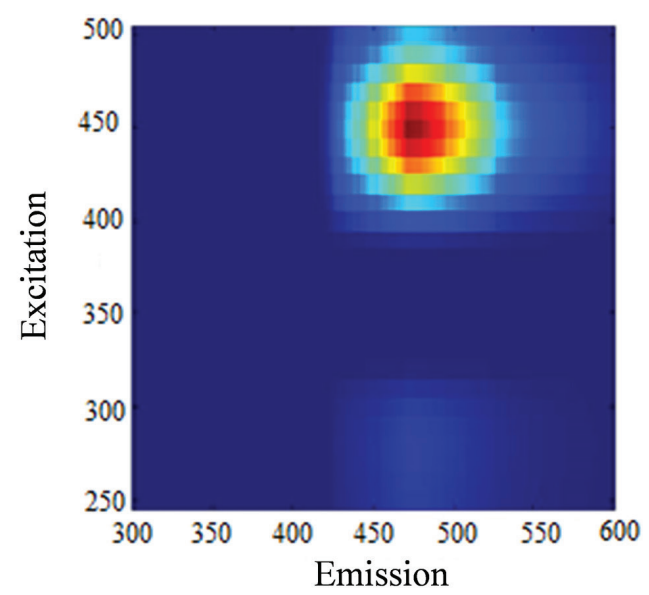

(b) Component 2

Figure 5. Component 1 (a) and component 2 (b) identified through canonical polyadic/parallel factor analysis (CP/PARAFAC) in the excitation-emission matrixes fluorescence spectra of dissolved organic matter in both soils (Amazonian dark earth and surrounding soil). 

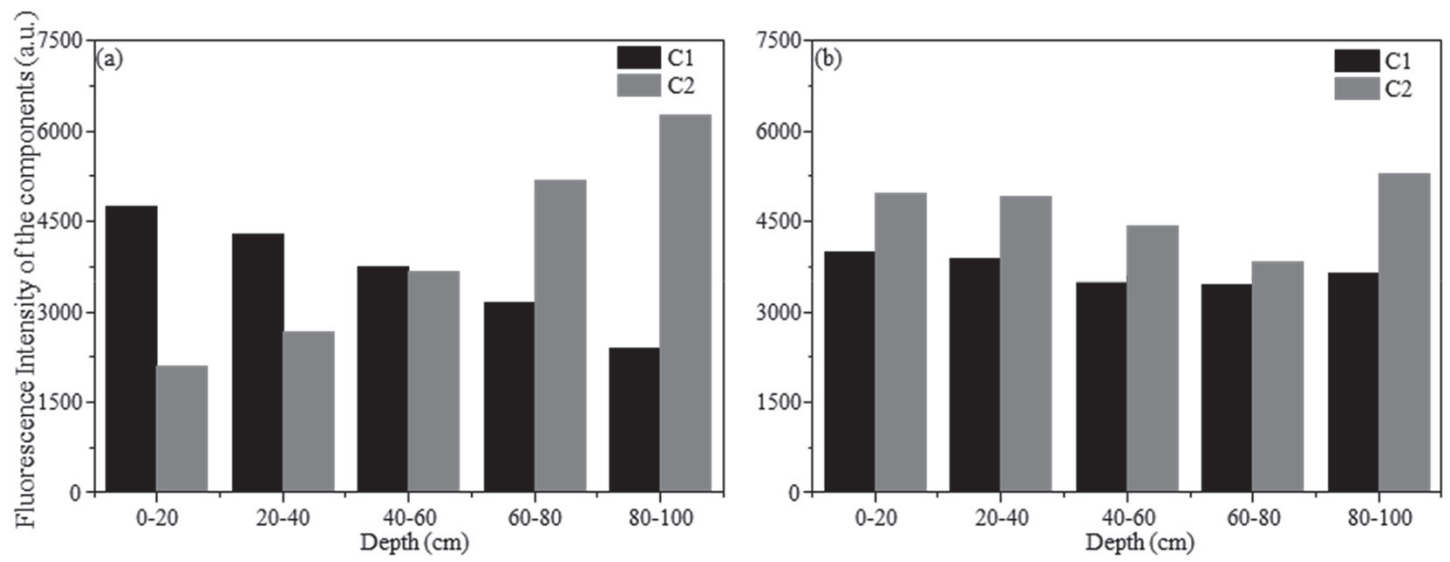

Figure 6. Fluorescence intensity contribution of the components $1(\mathrm{C} 1)$ and component (C2) identified through canonical polyadic/parallel factor analysis (CP/PARAFAC) in the fluorescence excitation-emission matrixes of DOM from the (a) Amazonian dark earth and (b) surrounding soil.

organic wastes by the pre-Columbian population. ${ }^{49}$ The fire promoted reactions such as dehydration and condensation, thereby generating OM that was more hydrophobic than that in the SR. The hydrophobic SOM was mainly in the top layer, thereby suggesting that the layer most altered by anthropogenic action was at the surface. Beyond the nutrient contents that were present in the $\mathrm{OM},{ }^{11,12,68}$ the alkaline extraction showed a greater interaction of SOM with aluminum from soil minerals. Both hydrophobicity and interactions with minerals play an important role in SOM stabilization, ${ }^{27}$ thereby increasing the thermodynamic stability as pointed out by DTG. The hydrophobicity and mineral/nutrient bonds can increase the supramolecular arrangement as well as the molecular rigidity, ${ }^{60,69}$ thereby restricting microbial access. These might have been factors that helped the resilience of SOM over thousands of years rather than just the aromatic nature of black carbon.

The SR had less OM and a more polar arrangement than ADE, which facilitated its degradation and made it less resilient. For these reasons, the litter is essential to the Amazonian region for delivering nutrients and sustaining the forest. ${ }^{70}$ Because of the temperature, rainfall, and microbiological diversity, the $\mathrm{OM}$ of the top layer is easily degraded. Therefore, the OM stability from ADE may be useful for reproducing a model of anthropogenic OM to create new anthropic soils that improve the soil properties and OM quality. ${ }^{10}$

\section{Conclusions}

ADE soil is richer in chemical elements than the SR (mainly carbon, nitrogen, calcium, magnesium, phosphorus, zinc, copper, and manganese), except for the typical minerals of the SR. SOM-ADE appeared to be more protected than that of the SR with organo-mineral interaction with nutrients and soil minerals. Furthermore,
SOM-ADE presented an arrangement that was more hydrophobic in the top layer because the aromatic units and the arrangement changed with depth, thereby decreasing the aromatic units and increasing the small molecules with substituent groups. The SOM from the SR presented an arrangement that was composed of small molecules with polar groups in the top layer. In deeper layers, the arrangement was composed of more hydrophobic units, but this hydrophobicity was mainly caused by aliphatic units.

SOM-ADE from the top layer differed most from the others, and had more complex structures because the layer was more impacted. SOM-ADE likely underwent two processes of stabilization, namely (i) hydrophobic stabilization by anthropogenic burning and (ii) organomineral stabilization. Thus, the different arrangement between the SOM and the organo-mineral interaction is of great importance to carbon stocks in the soils.

\section{Supplementary Information}

Supplementary data are available free of charge at http://jbcs.sbq.org.br as a PDF file.

\section{Acknowledgments}

This work was supported by Fundação de Amparo à Pesquisa do Estado de São Paulo (FAPESP) (grant No. 15/22954-1, 2018/15733-7, and 2017/15733-7) and the National Council for Scientific and Technological Development (CNPq). L. R. B. acknowledges the scholarship from FAPESP (2017/05575-2). O. P. F. acknowledges the financial support from FUNCAP (PRONEX PR2-0101-00006.01.00/15). The authors would like to thank Dr Roland Redon and Dr Stéphane Mounier (Laboratoire MIO, Université de Toulon, France) for providing the statistical analysis software (CP/ 
PARAFAC). Furthermore, we appreciate the contributions of the anonymous reviewers that helped to improve the manuscript quality.

\section{Author Contributions}

Lucas Raimundo Bento was responsible for conceptualization, investigation, writing-original draft, writing-review and editing; Isabela Carreira Constantino for formal analysis and writing- review and editing; Amanda Maria Tadini for formal analysis and writing- review and editing; Camila de Almeida Melo for conceptualization, supervision and writing-review and editing; Odair Pastor Ferreira for conceptualization, writing-review and editing; Altair Benedito Moreira for conceptualization, resources, supervision and writing- review and editing; Márcia Cristina Bisinoti for conceptualization, resources, funding acquisition, supervision, writing- review and editing.

\section{References}

1. Batjes, N. H.; Dijkshoorn, J. A.; Geoderma 1999, 89, 273.

2. Coe, M. T.; Marthews, T. R.; Costa, M. H.; Galbraith, D. R.; Greenglass, N. L.; Imbuzeiro, H. M. A.; Levine, N. M.; Malhi, Y.; Moorcroft, P. R.; Muza, M. N.; Powell, T. L.; Saleska, S. R.; Solorzano, L. A.; Wang, J.; Philos. Trans. R. Soc., B 2013, 368, DOI 10.1098/rstb.2012.0155.

3. Kern, D. C. In Amazonian Dark Earth; Lehmann, J.; Kern, D. C.; Glaser, B.; Woods, W. I., eds.; Springer: Netherlands, 2004, p. 51-75.

4. Taube, P. S.; Hansel, F. A.; Madureira, L. A. S.; Teixeira, W. G.; Org. Geochem. 2013, 58, 96.

5. Glaser, B.; Birk, J. J.; Geochim. Cosmochim. Acta 2012, 82, 39.

6. Clement, C. R.; Denevan, W. M.; Heckenberger, M. J.; Junqueira, A. B.; Neves, E. G.; Teixeira, W. G.; Woods, W. I.; Proc. R. Soc. B 2015, 282, DOI 10.1098/rspb.2015.0813.

7. Sombroek, W.; Kern, D.; Rodrigues, T.; Cravo, M. D. S.; Cunha, T. J. F.; Woods, W.; Glaser, B. In As Terras Pretas de Índio da Amazônia: Sua Caracterização e Uso deste Conhecimento na Criação de Novas Áreas; Teixeira, W. G.; Kern, D. C.; Madari, B. E.; Lima, H. N.; Woods, W., eds.; Embrapa Amazônia Ocidental: Manaus, 2009, p. 251-257.

8. Fraser, J.; Teixeira, W.; Falcão, N.; Woods, W.; Lehmann, J.; Junqueira, A. B.; Area 2011, 43, 264.

9. Kern, J.; Giani, L.; Teixeira, W.; Lanza, G.; Glaser, B.; Catena 2019, 172, 104.

10. Novotny, E. H.; Hayes, M. H. B.; Madari, B. E.; Bonagamba, T. J.; de Azevedo, E. R.; de Souza, A. A.; Song, G.; Nogueira, C. M.; Mangrich, A. S.; J. Braz. Chem. Soc. 2009, 20, 1003.

11. Oliveira, N. C.; Paschoal, A. R.; Paula, R. J.; Constantino, I. C.; Bisinoti, M. C.; Moreira, A. B.; Fregolente, L. G.; Santana, A.
M.; Sousa, F. A.; Ferreira, O. P.; Paula, A. J.; Geoderma 2018, 311,58 .

12. Archanjo, B. S.; Baptista, D. L.; Martinz-Ferreira, E. H.; Soares, J. R.; Cançado, L. G.; Falcão, N. P. S.; dos Santos, H. F.; Achete, C. A.; Jorio, A.; Achete, C. A.; Microsc. Microanal. 2012, 18, 1502.

13. Rosa, A. H.; Simões, M. L.; de Oliveira, L. C.; Rocha, J. C.; Neto, L. M.; Milori, D. M. B. P.; Geoderma 2005, 127, 1.

14. Bento, L. R.; Castro, A. J. R.; Moreira, A. B.; Ferreira, O. P.; Bisinoti, M. C.; Melo, C. A.; Geoderma 2019, 334, 24.

15. Kambo, H. S.; Dutta, A.; Renewable Sustainable Energy Rev. 2015, 45, 359.

16. Piccolo, A.; Soil Sci. 2001, 166, 810.

17. Piccolo, A.; Adv. Agron. 2002, 75, 57.

18. Nebbioso, A.; Piccolo, A.; Biomacromolecules 2011, $12,1187$.

19. Drosos, M.; Nebbioso, A.; Piccolo, A.; Appl. Soil Ecol. 2018, $123,513$.

20. Zsolnay, Á.; Geoderma 2003, 113, 187.

21. Stevenson, F. J. In Humus Chemistry: Genesis, Composition, Reactions, $2^{\text {nd }}$ ed.; John Wiley \& Sons: New York, USA, 1994, p. 285-302.

22. Drosos, M.; Piccolo, A.; Land Degrad. Dev. 2018, 29, 1792.

23. Piccolo, A.; Spaccini, R.; Drosos, M.; Vinci, G.; Cozzolino, V. In The Future of Soil Carbon; Garcia, C.; Nannipieri, P.; Hernandez, T., eds.; Elsevier: London, United Kingdom, 2018, p. 87-124.

24. Kaiser, K.; Guggenberger, G.; Org. Geochem. 2000, 31, 711.

25. Kaiser, K.; Guggenberger, G.; Eur. J. Soil Sci. 2007, 58, 45.

26. Guggenberger, G.; Kaiser, K.; Geoderma 2003, 113, 293.

27. Dungait, J. A. J.; Hopkins, D. W.; Gregory, A. S.; Whitmore, A. P.; Glob. Chang. Biol. 2012, 18, 1781.

28. Shang, C.; Tiessen, H.; Soil Sci. Soc. Am. J. 1998, 62, 1247.

29. Wagai, R.; Mayer, L. M.; Geochim. Cosmochim. Acta 2007, $71,25$.

30. Brunetti, G.; Mezzapesa, G. N.; Traversa, A.; Bonifacio, E.; Farrag, K.; Senesi, N.; D’Orazio, V.; Clean: Soil, Air, Water 2016, 44, 1375.

31. Empresa Brasileira de Pesquisa Agropecuária (EMBRAPA); Sistema Brasileiro de Classificação de Solos; Santo, H. G.; Jacomine, P. K. T.; Anjos, L. H.; Oliveira, J. B.; Coelho, M. R.; Lumbreras, J. F.; Cunha, T. J. F., eds.; EMBRAPA: Brasília, 2006.

32. Schellekens, J.; Almeida-Santos, T.; Macedo, R. S.; Buurman, P.; Kuyper, T. W.; Vidal-Torrado, P.; Geoderma 2017, 288, 154.

33. Pagano, M. C.; Ribeiro-Soares, J.; Cançado, L. G.; Falcão, N. P. S.; Gonçalves, V. N.; Rosa, L. H.; Takahashi, J. A.; Achete, C. A.; Jorio, A.; Soil Tillage Res. 2016, 155, 298.

34. Traversa, A.; D’Orazio, V.; Mezzapesa, G. N.; Bonifacio, E.; Farrag, K.; Senesi, N.; Brunetti, G.; Chemosphere 2014, 111, 184.

35. Tadini, A. M.; Nicolodelli, G.; Senesi, G. S.; Ishida, D. A.; Montes, C. R.; Lucas, Y.; Mounier, S.; Guimarães, F. E. G.; Milori, D. M. B. P.; Sci. Total Environ. 2018, 613-614, 160. 
36. Orazio, V. D.; Traversa, A.; Senesi, N.; Plant Soil 2014, 374, 473.

37. Empresa Brasileira de Pesquisa Agropecuária (EMBRAPA); Manual de Métodos de Análise de Solo; Teixeira, P. C.; Donagemma, G. K.; Teixeira, W. G.; Fontana, A., eds.; EMBRAPA: Brasília, 2017.

38. United States Environmental Protection Agency (US EPA); Method 3050B: Acid Digestion of Sediments, Sludges, and Soils; US EPA: Washington, 1996.

39. ASTM D2974-14: Standard Test Methods for Moisture, Ash, and Organic Matter of Peat and Other; West Conshohocken, 2014.

40. Schwertmann, U.; Z. Pflanzenernaehr. Bodenkd. 1964, 105, 194.

41. Mehra, O. P.; Jackson, M. L.; Clays Clay Miner. 1958, 7, 317.

42. McKeague, J.; Brydon, J. E.; Miles, N. M.; Soil Sci. Soc. Am. J. 1971, 35, 33.

43. de Melo Benites, V.; de Sá Mendonça, E.; Schaefer, C. E. G. R.; Novotny, E. H.; Reis, E. L.; Ker, J. C.; Geoderma 2005, 127, 104.

44. Bro, R.; Chemom. Intell. Lab. Syst. 1997, 38, 149.

45. Mounier, S.; Patel, N.; Quilici, L.; Benaim, J. Y.; Benamou, C.; Water Res. 1999, 33, 1523.

46. Mounier, S.; Zhao, H.; Garnier, C.; Redon, R.; Biogeochemistry 2011, 106, 107.

47. Luciani, X.; Mounier, S.; Redon, R.; Bois, A.; Chemom. Intell. Lab. Syst. 2009, 96, 227.

48. Jiang, T.; Kaal, J.; Liang, J.; Zhang, Y.; Wei, S.; Wang, D.; Green, N. W.; Sci. Total Environ. 2017, 603-604, 461.

49. Barbosa, J. Z.; Motta, A. C. V.; Corrêa, R. S.; Melo, V. F.; Muniz, A. W.; Martins, G. C.; Silva, L. C. R.; Teixeira, W. G.; Young, S. D.; Broadley, M. R.; Geoderma 2020, 361, 114085.

50. da Costa, M. L.; Kern, D. C.; Kampf, N. In Amazonian Dark Earths: Origin Properties Management; Lehmann, J.; Kern, D. C.; Glaser, B.; Woods, W. I., eds.; Springer: Netherlands, 2003, p. 505 .

51. Schwertmann, U.; Nature 1966, 212, 645.
52. Bento, L. R.; Melo, C. A.; Ferreira, O. P.; Moreira, A. B.; Mounier, S.; Piccolo, A.; Spaccini, R.; Bisinoti, M. C.; Sci. Total Environ. 2020, 708, 135000.

53. Poggere, G. C.; Inda, A. V.; Barrón, V.; Kämpf, N.; de Brito, A. D. B.; Barbosa, J. Z.; Curi, N.; Appl. Clay Sci. 2018, 161, 385.

54. Eusterhues, K.; Rumpel, C.; Kögel-Knabner, I.; Eur. J. Soil Sci. 2005, 56, 753.

55. Kleber, M.; Lehmann, J.; J. Environ. Qual. 2019, 48, 207.

56. Lehmann, J.; Kleber, M.; Nature 2015, 528, 60.

57. Myneni, S. C. B.; J. Environ. Qual. 2019, 48, 233.

58. Olk, D. C.; Bloom, P. R.; Perdue, E. M.; McKnight, D. M.; Chen, Y.; Farenhorst, A.; Senesi, N.; Chin, Y.-P.; Schmitt-Kopplin, P.; Hertkorn, N.; Harir, M.; J. Environ. Qual. 2019, 48, 217.

59. Incerti, G.; Bonanomi, G.; Giannino, F.; Cartenì, F.; Spaccini, R.; Mazzei, P.; Piccolo, A.; Mazzoleni, S.; Plant Soil 2017, 411, 377.

60. Nebbioso, A.; Piccolo, A.; Environ. Sci. Technol. 2009, 43, 2417.

61. Bravard, S.; Righi, D.; Geoderma 1991, 48, 151.

62. de Paolis, F.; Kukkonen, J.; Chemosphere 1997, 34, 1693.

63. Senesi, N.; Miano, T. M.; Provenzano, M. R.; Brunetti, G.; Soil Sci. 1991, 152, 259.

64. Bro, R.; Kiers, H. A. L.; J. Chemom. 2003, 17, 274.

65. Cocozza, C.; D’Orazio, V.; Miano, T. M.; Shotyk, W.; Org. Geochem. 2003, 34, 49.

66. Lipski, M.; Sławiński, J.; Zych, D.; J. Fluoresc. 1999, 9, 133.

67. Tadini, A. M.; Nicolodelli, G.; Mounier, S.; Montes, C. R.; Milori, D. M. B. P.; Sci. Total Environ. 2015, 537, 152.

68. Archanjo, B. S.; Araujo, J. R.; Silva, A. M.; Capaz, R. B.; Falcão, N. P. S.; Jorio, A.; Achete, C. A.; Environ. Sci. Technol. 2014, 48,7445 .

69. Nuzzo, A.; Sánchez, A.; Fontaine, B.; Piccolo, A.; J. Geochem. Explor. 2013, 129, 1.

70. da Silva, W. B.; Périco, E.; Dalzochio, M. S.; Santos, M.; Cajaiba, R. L.; For. Ecol. Manage. 2018, 429, 189.

Submitted: January 17, 2020 Published online: March 18, 2020 